Original Article

\title{
Providing inoculum for Didymella bryoniae studies: the effect of light spectrum and storing at low temperature
}

\author{
Fornecendo inóculo para estudos de Didymella bryoniae: o efeito do espectro de luz e \\ armazenamento em baixa temperatura
}

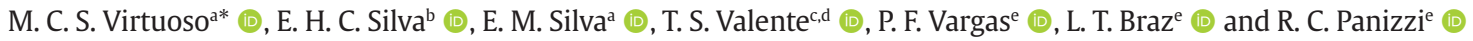 \\ aUniversidade Estadual Paulista - UNESP, Faculdade de Ciências Agrárias e Veterinárias, Programa de Pós-graduação em Agronomia (Genética e \\ Melhoramento de Plantas), Jaboticabal, SP, Brasil \\ 'Instituto Taquaritinguense de Ensino Superior “Dr. Aristides de Carvalho Schlobach” - ITES, Departamento de Agronomia, Taquaritinga, SP, \\ Brasil \\ 'University of Alberta - UAlberta, Department of Agricultural, Food and Nutritional Science, Edmonton, Canada \\ ¿Universidade Estadual Paulista - UNESP, Faculdade de Ciências Agrárias e Veterinárias, Departamento de Zootecnia, Jaboticabal, SP, Brasil \\ eUniversidade Estadual Paulista - UNESP, Faculdade de Ciências Agrárias e Veterinárias, Departamento de Ciências da Produção Agrícola, \\ Jaboticabal, SP, Brasil
}

\begin{abstract}
The in vitro sporulation of Didymella bryoniae is of great importance for studies that require pure inoculum and in large quantities. Thus, the objectives of this study were to identify the best condition for $D$. bryoniae sporulation combining different light spectra (UV-A or UV-B light, white light, and continuous dark), with distinct culture media (PDA, V8, ML, and PDAB) and, to evaluate fungus' survivability stored at $-20^{\circ} \mathrm{C}$ over time. The fungus samples were only able to sporulate when subjected to the UV-B light treatment, regardless of the culture medium. The highest appearance of spores conidium type was observed in the PDAB medium, and the lowest production occurred in the ML medium. Reproductive structures, such as perithecia and pycnidia, were observed in all culture media. However, there was considerable variation in the amount of each structure between the different culture media. The ML and V8 media showed a greater number of perithecia and the PDA and PDAB media presented a greater proportion of pycnidia compared to perithecia. The storage duration at $-20^{\circ} \mathrm{C}$ did not affect mycelial growth or mycelial growth rate. In conclusion, the UV-B light is essential for D. bryoniae in vitro sporulation. Moreover, the culture medium composition influences the type of fungal structure produced, as well as spores' size and quantity. Freezing at $-20^{\circ} \mathrm{C}$ is an efficient technique that can be used to store $D$. bryoniae for at least five months without loss of viability.
\end{abstract}

Keywords: fungi preservation, gummy stem blight, sporulation, UV-B light.

\begin{abstract}
Resumo
A esporulação de Didymella bryoniae in vitro é de grande importância para estudos que requerem inóculo puro e em grandes quantidades. Assim, os objetivos deste estudo foram identificar a melhor condição para esporulação de $D$. bryoniae combinando diferentes espectros de luz (luz UV-A ou UV-B, luz branca e escuro contínuo) com distintos meios de cultura (PDA, V8, ML e PDAB) e, avaliar a sobrevivência do fungo armazenado a $-20^{\circ} \mathrm{C}$ ao longo do tempo. As amostras de fungo só esporularam quando submetidas ao tratamento com luz UV-B, independentemente do meio de cultura. Maior aparecimento de esporos do tipo conídio foi observado no meio PDAB, e a menor produção ocorreu no meio ML. Estruturas reprodutivas, como peritécios e picnídeos, foram observadas em todos os meios de cultura. No entanto, houve uma variação considerável na quantidade de cada estrutura entre os diferentes meios de cultura. Os meios ML e V8 apresentaram maior número de peritécios e os meios PDA e PDAB apresentaram maior proporção de picnídeos em relação aos peritécios. A duração do armazenamento a $-20^{\circ} \mathrm{C}$ não afetou o crescimento micelial ou a taxa de crescimento micelial. Em conclusão, a luz UV-B é essencial para a esporulação de $D$. bryoniae in vitro. Além disso, a composição do meio de cultura influencia o tipo de estrutura fúngica produzida, bem como o tamanho e a quantidade dos esporos. O congelamento a $-20^{\circ} \mathrm{C}$ é uma técnica eficiente que pode ser usada para armazenar $D$. bryoniae por pelo menos cinco meses sem perda de viabilidade
\end{abstract}

Palavras-chave: Preservação de fungos, crestamento gomoso do caule, esporulação, Luz UV-B.

*e-mail: marcos.virtuoso@unesp.br

Received: June 18, 2021 - Accepted: September 30, 2021 


\section{Introduction}

The Didymella bryoniae (Auersw.) Rehm, synonym Stagonosporopsis cucurbitacearum (Fr.) [anamorph Phoma cucurbitacearum (Fr.) Sacc (=Ascochyta cucumis Fautrey \& Roum)] (Mao et al., 2020), is an ascomycete that causes the gummy stem blight (GSB) in several cucurbits. When present in cucurbits cultures this fungus might negatively impact yield with direct consequent economic revenue decreases for growers (Liu et al., 2017). Given the importance of $D$. bryoniae, studies involving in vitro cultivation and sporulation are relevant, especially when a large amount of pure inoculum is needed. For example, screening for resistant plants requires a high number of spores to guarantee the intensity of the disease. Moreover, GSB-related studies often require the combination of inoculations in a greenhouse and subsequent field tests (Gusmini et al., 2003).

To date, several studies evaluating the best condition for $D$. bryoniae sporulation in vitro have been reported, testing different culture medium (CM) combinations (Gusmini et al., 2003; Hassan et al., 2018; Leão et al., 2012; Nga et al., 2010; Skarshaug, 1981; Somai et al., 2002), ultraviolet (UV) light (Kwon et al., 1997; Lee, 1982; Tsay et al., 1990; Tsutsumi and Silva, 2004; Wolukau et al., 2007; Zhang et al., 2017), and temperature and pH (Bhat et al., 2009). However, despite the vast literature on the subject, there is still no consensus among researchers on the main factors influencing in vitro $D$. bryoniae sporulation, with frequent disagreement between studies.

According to Keinath et al. (1995) and Wiant (1945), some isolates do not sporulate in any CM. On the other hand, Leão et al. (2012) observed that the CM can influence D. bryoniae sporulation. In addition, Choi et al. (2010) and Kwon et al. (1997) concluded that the presence of UV light is important to promote the sporulation of this fungus. Despite the direct effect that UV light may have on $D$. bryoniae sporulation, many studies do not classify the type of UV used, hampering the use of a similar methodology. Such information is important because UV lights can be classified according to the emitted wavelength, being UV-A (315-400 nm), UV-B (280-315 nm), or UV-C (100-280 nm) (Braga et al., 2015).

In addition to the CM and the type of light, the storage time is also important for the development of research with $D$. bryoniae. Properly stored samples serve as quick-access natural resources banks, which can be used for the development of studies on biodiversity, systematics, phytopathology, and related areas, such as plant breeding for resistance to diseases (Aparecido et al., 2018; Hawksworth and Colwell 1992; Sakr, 2019). The most used methods for fungi preservation are submersion in sterile water, mineral oil, or glycerol, use of filter paper discs, wood, soil, and silica gel (Al-Bedak et al., 2019). Also, cryopreservation, lyophilization, and preservation under liquid nitrogen can be employed (Ayala-Zermeño et al., 2017).

Freezing at $-20^{\circ} \mathrm{C}$ has also been shown to be a safe method for storing various microorganisms and, unlike cryopreservation and preservation under liquid nitrogen, which requires more sophisticated equipment, storing at $-20^{\circ} \mathrm{C}$ is simple and of low cost (Tortora et al., 2011). To the best of our knowledge, only Grube et al. (2011) used freezing at $-20^{\circ} \mathrm{C}$ for the storage of $D$. bryoniae isolates. However, these authors did not carry out systematic evaluations to verify the preservation and survival of the fungus over time, nor of its structures. Thus, little is known about the survival capacity of $D$. bryoniae stored at low temperatures.

Based on the above considerations, there is a need to establish the ideal condition for in vitro $D$. bryoniae sporulation, as well as to evaluate the survival capacity of this fungus when stored at low temperature. Thus, the objectives of the present study were to establish the best condition for $D$. bryoniae sporulation combining different light spectra and culture media, and to evaluate the fungus' ability to survive over time when submitted to the $-20^{\circ} \mathrm{C}$ storage.

\section{Material and Methods}

The present study was carried out at São Paulo State University, School of Agricultural and Veterinarian Sciences, Jaboticabal Campus ( $21^{\circ} 15^{\prime} 19^{\prime \prime}$ S, 48 ${ }^{\circ} 19^{\prime} 21^{\prime \prime}$ O), São Paulo Brazil. Melon plants (Cucumis melo L.) with symptoms of GSB, such as the presence of viscous exudate and fruiting bodies of the fungus, were used to obtain the $D$. bryoniae isolate. The pycnidia/perithecium were directly removed from lesions on the stem was performed with the aid of a magnifying glass. These structures were placed in Petri dishes containing PDA (potato-dextrose-agar) medium, subsequently closed with PVC film, and incubated in growth chambers, with a constant temperature of $24^{\circ} \mathrm{C}$ and a 12-hour photoperiod for 4 consecutive days. After obtaining the fungal culture, a subculture was carried out to purify the fungus, transferring $5 \mathrm{~mm}$ diameter discs with mycelium to new plates and conditioning them for 10 days, forming the stock cultures.

The study was conducted in two stages to assess the ability of in vitro sporulation and survival after freezing. In the first phase of the study, a completely randomized design was used in a $4 \times 4$ factorial scheme with 10 repetitions, the factors being represented by the different culture media and types of light. In the second phase, the growth capacity was evaluated after different periods of freezing at $-20^{\circ} \mathrm{C}$.

\subsection{Culture medium and light spectrum}

To evaluate the sporulation capacity of $D$. bryoniae, four culture media were used, namely: $i$ ) potato-dextrose-agar (PDA), ii) concentrated vegetable juice (V8, commercial product), iii) melon leaf extract (ML), and $i v$ ) potatodextrose-agar + melon branches (PDAB). In addition, four light spectra were used, being: $i$ ) white fluorescent light 440-740 nm/10W, ii) UV-A white fluorescent light, 350-400 nm/8W, iii) UV-B white fluorescent light, 280-360 nm/8W, and iv) control group in continuous dark.

PDA and PDAB culture media were prepared with $200 \mathrm{~g}$ of potatoes chopped into small cubes and placed in $1.0 \mathrm{~L}$ of deionized water and cooked at $100^{\circ} \mathrm{C}$ for 20 minutes. To the potato extract, $20 \mathrm{~g}$ of dextrose and $20 \mathrm{~g}$ of agar were added, completing the volume with deionized water to $1.0 \mathrm{~L}$. For the preparation of the $\mathrm{V} 8$ medium, $20 \mathrm{~g}$ of agar was added to $200 \mathrm{~mL}$ of concentrated vegetable juice, then the volume was adjusted to $1.0 \mathrm{~L}$, and finally, 
$3.2 \mathrm{~g}$ of $\mathrm{CaCO}_{3}$ was added to raise the $\mathrm{pH}$ to 7.0. For the ML medium, 200g of melon leaves were washed in running water and then processed in a blender with $500 \mathrm{~mL}$ of deionized water, then sieved twice in non-woven fabrics (TNT) and then added with $20 \mathrm{~g}$ of agar and $20 \mathrm{~g}$ of dextrose, completing the process. volume to $1.0 \mathrm{~L}$. The $\mathrm{pH}$ of all culture media was assessed and, when necessary, adjusted to standardize at 7.0.

After preparation, all culture media were sterilized by autoclaving for 20 minutes at $121^{\circ} \mathrm{C}$, then $200 \mathrm{mg}$ of antibiotic (streptomycin) was added. Subsequently, $5 \mathrm{~mL}$ of each medium was poured into test tubes ( $14.5 \mathrm{x}$ $2.5 \mathrm{~cm}$ ). In this step, three pieces of $5 \mathrm{~cm}$ melon branches were added to the PDAB medium, previously disinfected in $1 \%$ bleach, and dried on filter paper. Finally, the tubes were covered with cotton, sealed with aluminum foil, and again autoclaved.

At the beginning of the experiment, $5 \mathrm{~mm}$ diameter discs with mycelium of the fungus were removed from the stock plates and transferred to the center of each test tube. Subsequently, the tubes were incubated in a growth chamber with a constant temperature of $24^{\circ} \mathrm{C}$ and subjected to a photoperiod of 16 hours of light, except for the continuous dark treatment, for 20 consecutive days. During this photoperiod, all tubes were placed $20 \mathrm{~cm}$ away from the lamps allowing maximum possible radiation.

The spore concentration was determined for all treatments after 20 days of incubation, using a hemacytometer. For the solution preparation, the culture medium was removed from the tube and placed in a crucible with $20 \mathrm{~mL}$ of sterile water, then macerated to release the spores. After maceration, filtration in voile tissue was carried out to remove remnants of the culture medium and mycelium, followed by the addition of $0.2 \%$ Tween 20. The results were expressed as number of spores per $\mathrm{mL}$. In addition, the mycelium staining, type of sexual structures (perithecia and pycnidia), and the spore morphology were visually evaluated with the aid of an optical microscope with an attached camera (Olympus cellSens standard 2.3). The morphological classification of spores followed the methodology proposed by Chiu and Walker (1949).

\subsection{Storing at $-20^{\circ} \mathrm{C}$}

To verify fungal survivability after different periods of storing at $-20^{\circ} \mathrm{C}$, a completely randomized design was employed, considering the storage time (in months) as treatment, with five repetitions. Following the aforementioned methodology, PDAB tubes were prepared and then conditioned in the growth chamber under UV-B light to sporulate. After the fungus had sporulated, tubes were taken to a freezer $\left(-20^{\circ} \mathrm{C}\right)$ and stored for up to five consecutive months.

A tube of PDAB medium was removed from the freezer every 30 days of storage to obtain $D$. bryoniae fungal structures. These samples were transferred to five Petri dishes containing PDA medium, which were sealed with plastic film and incubated in a growth chamber at a constant temperature of $24^{\circ} \mathrm{C}$, with a 12 -hour photoperiod and white fluorescent light regime.

In this phase, daily evaluations of mycelial growth were performed, measuring two diametrically opposite points of the colony perimeter, discounting $10.0 \mathrm{~mm}$ corresponding to the initial inoculum of the fungus, for five consecutive days. The data were used to calculate the average mycelial growth at five days and to obtain the mycelial growth rate index (MGRI), using the method proposed by Maia et al. (2011), as follow (Equation 1):

$$
M G R I=\frac{\sum\left(D-D_{a}\right)}{N}
$$

where $D$ is the current average diameter of the colony, $D_{a}$ is the average diameter of the colony of the previous day, and $N$ is the number of days of evaluation.

\subsection{Statistical analysis}

The spore concentration data were transformed to $\operatorname{root}(\mathrm{x})$ and subjected to analysis of variance and comparison of means by the Tukey test (Tukey, 1953). The data relating to AG and MGRI were submitted to analysis of variance. The analyzes were performed using software $R$ (R Development Core Team, 2018).

\section{Results}

There was no significant interaction between the culture medium and the type of light used to promote in vitro sporulation of $D$. bryoniae. The fungus samples were only able to sporulate when subjected to the UV-B light treatment, regardless of the culture medium. The other light conditions did not cause any stimulus to sporulation, or even traces of reproductive structures. As a result, comparisons using the mean test were only performed between different culture media under UV-B light treatment and, a significant difference was observed for the number of spores among the four culture medium evaluated $(P<0.001)$. The highest appearance of spores conidium type was observed in the PDAB medium, and the lowest production occurred in the ML medium (Figure 1).

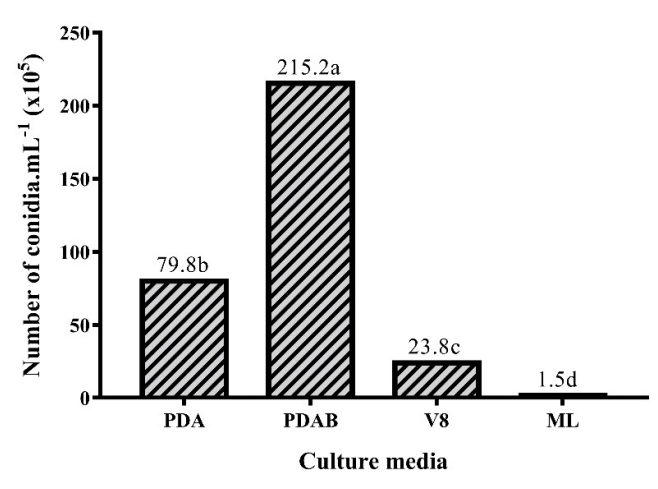

Figure 1. Average conidia concentration of Didymella bryoniae produced in different culture media under UV-B light. PDA = potatodextrose-agar; $\mathrm{PDAB}=$ potato-dextrose-agar + melon branches; $\mathrm{V} 8=$ concentrated vegetable juice (commercial); $\mathrm{ML}=$ melon leaf extract. 
Reproductive structures, such as perithecia and pycnidia, were observed in all culture media. However, there was considerable variation in the amount of each structure between the different culture media used as shown in Table 1. The ML and V8 media showed a greater number of perithecia in relation to the pycnidia. This variation might have influenced the final spore count since, despite a large number of structures the ascospores are difficult to visualize on the hemacytometer, resulting in reduced total spores' count. In contrast, the PDA and PDAB media presented a greater proportion of pycnidia compared to perithecia, resulting in a higher conidia appearance (Figure 1). It worth mentioning the importance of PDAB medium to promote pycnidia production since most of the formed structures were present in the melon branches.

The visual analysis employed for mycelium characterization indicated that the light type is an important factor affecting both the appearance and color of the fungus'

Table 1. Spores of Didymella bryoniae produced in different media under UV-B light.

\begin{tabular}{ccc}
\hline Culture media $^{\mathbf{a}}$ & Perithecia & Pycnidia \\
\hline PDAB & ++ & ++++ \\
PDA & ++ & +++ \\
V8 & +++ & ++ \\
ML & ++++ & + \\
\hline
\end{tabular}

+= scarce; ++ = moderate; +++ = good; ++++ = abundant. ${ }^{\mathrm{PPDAB}}=$ potatodextrose-agar + melon branches; PDA = potato-dextrose-agar; $\mathrm{V} 8=$ concentrated vegetable juice $($ commercial); $\mathrm{ML}=$ melon leaf extract structures. When submitted to growth in UV-B light, the mycelium showed a darker color (dark gray) compared to all other evaluated light conditions. Samples subjected to continuous dark, or UV-A light presented white color, and those under fluorescent light were greyish-white. In addition, it was observed that the mycelium volume is smaller when subjected to UV-B light but with a larger number of perithecia and pycnidia (Figure 2).

Regarding morphological aspects evaluated, the appearance of septate and non-septate conidia was observed in all culture media under UV-B light as shown in Figure 3A. However, an important size variation was observed in which the largest microconidium production occurred in the V8 medium, with structure size ranging from 3 to $5 \mu \mathrm{m}$. In the other culture media, there were a higher proportion of macroconidia, ranging from 6 to $10 \mu \mathrm{m}$ in length according to the classification proposed by Chiu and Walker (1949). Moreover, in all assessed media the asci's size ranged from 35 to $50 \mu \mathrm{m}$ and the ascospores from 6.5 to $12 \mu \mathrm{m}$ in length (Figure 3B).

As greater $D$. bryoniae sporulation was observed in samples submitted to PDAB medium and under UV-B light, this treatment was used to produce biological material for further freezing. At this stage of the experiment, the fungus survivability was evaluated after different storage periods at $-20^{\circ} \mathrm{C}$. However, there was no significant difference $(P>0.05)$ between the freezing times on mycelial growth and the mycelial growth rate index (Figure 4). This result indicates that when subjected to a combination of PDAB medium with UV-B light, the fungus can survive, and biological functions are preserved after freezing at $-20^{\circ} \mathrm{C}$ for up to five months.
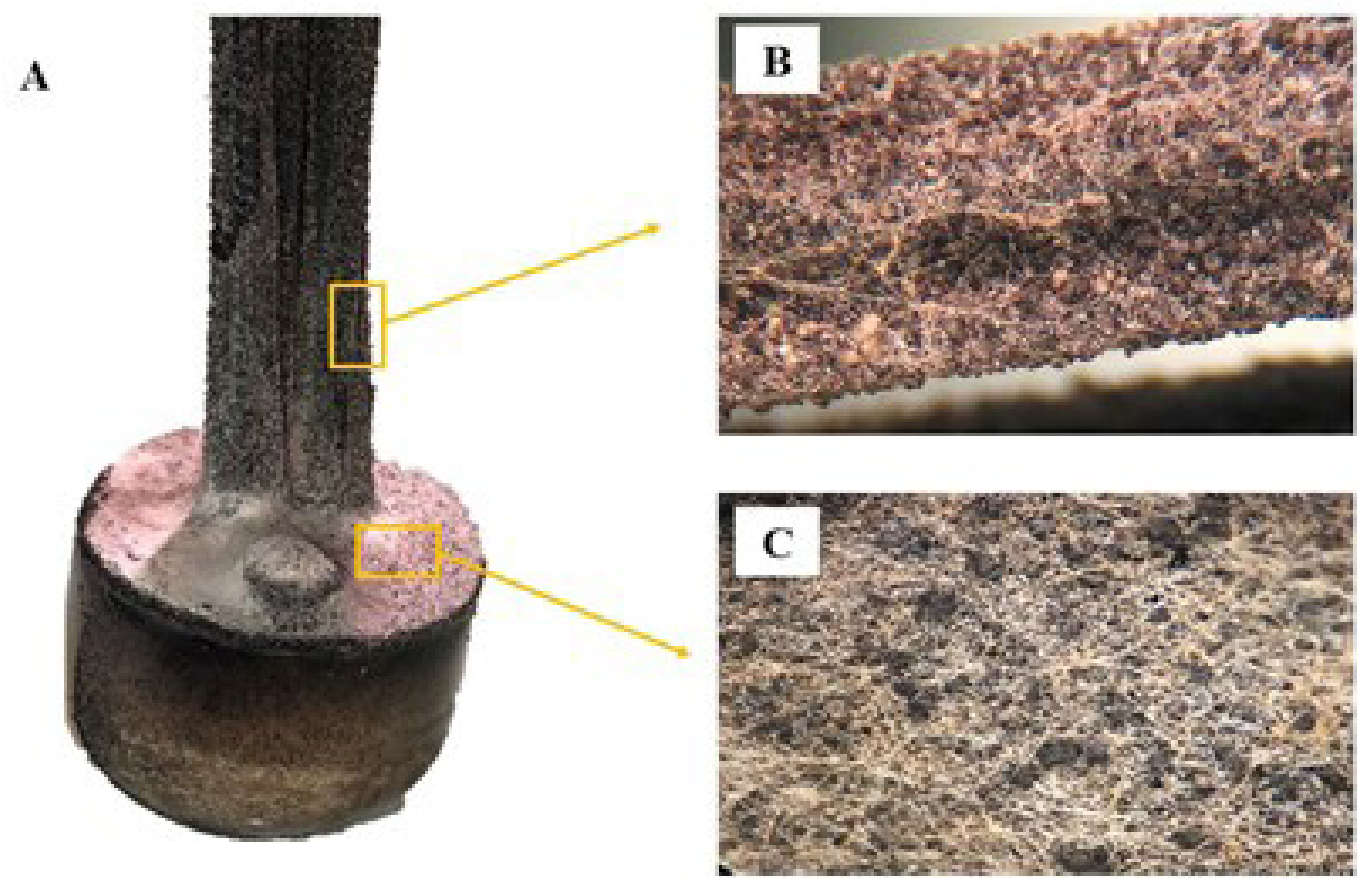

Figure 2. Characteristics of Didymella bryoniae reproductive structures in vitro. (A) PDAB medium = potato-dextrose-agar + melon branches, (B) on the branch; and (C) on the medium. 


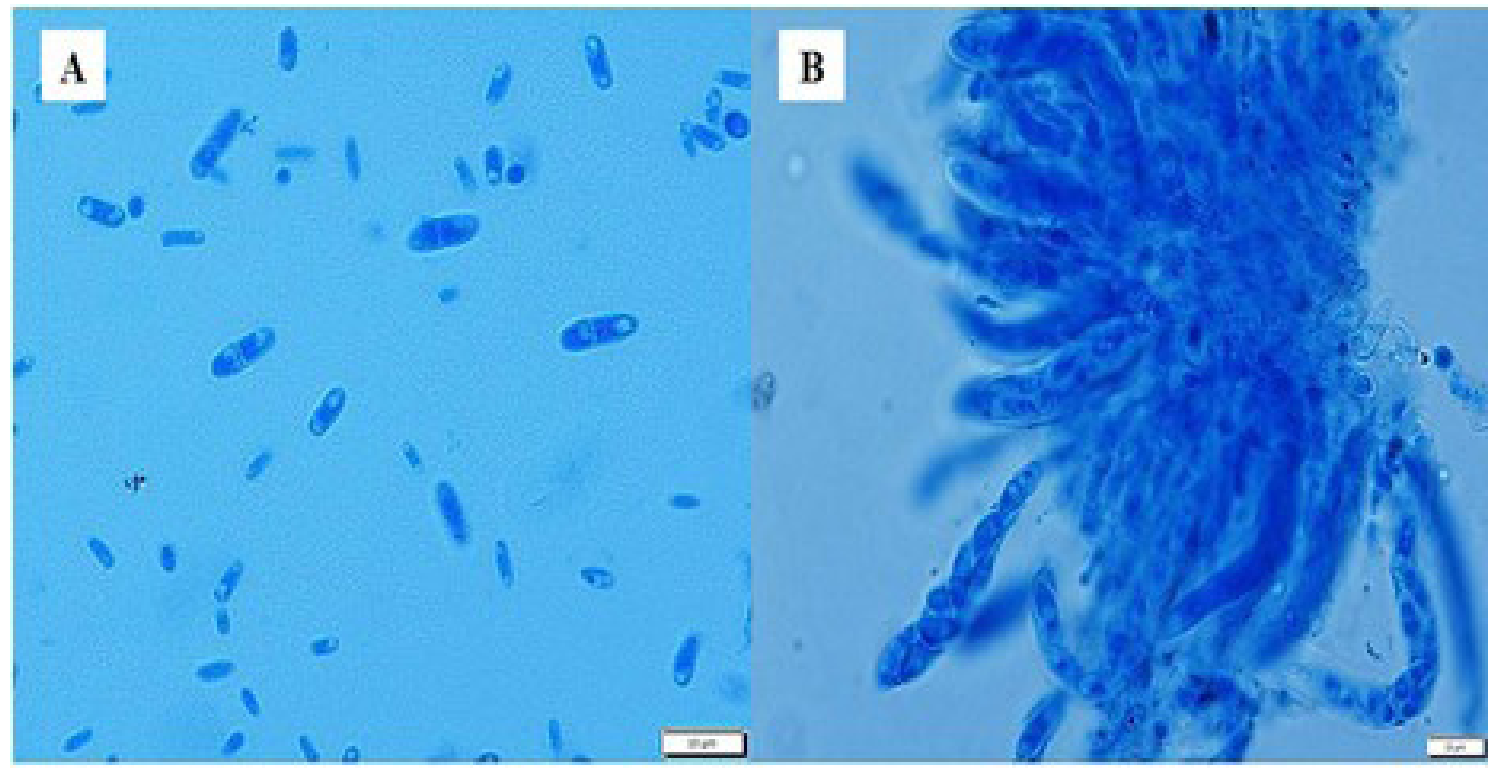

Figure 3. (A) Conidia of the imperfect form of Didymella bryoniae; (B) Asci and ascospores of the perfect form of Didymella bryoniae $(100 \mathrm{x}$ amplification, scale $=10 \mu \mathrm{m})$.
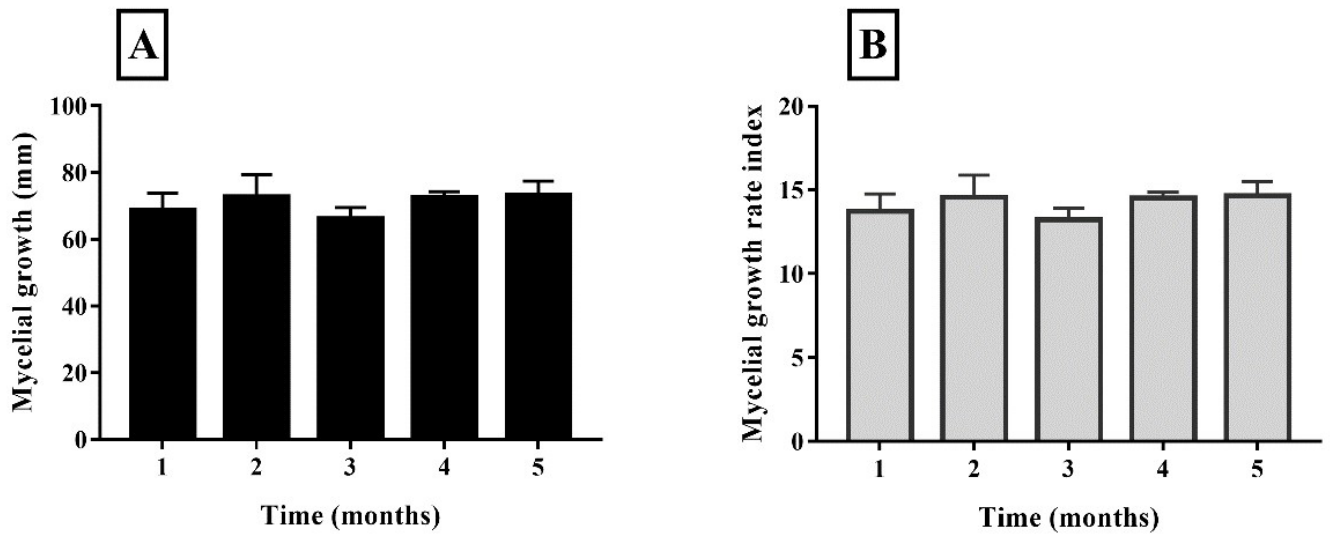

Figure 4. Average values of mycelial growth (A) and mycelial growth rate index (B) for the Didymella bryoniae fungus stored over five consecutive months at $-20^{\circ} \mathrm{C}$.

\section{Discussion}

The results obtained in our study showed that regardless of the culture medium, the in vitro sporulation of Didymella bryoniae isolate occurs only in the presence of ultraviolet radiation, more specifically, the light spectrum in the wavelength between $280-360 \mathrm{~nm}$ (peaking at $315 \mathrm{~nm}$ ). According to Sepúlveda et al. (2009), some photoreceptors are only activated when stimulated by light with specific wavelengths. In addition, other authors reported that in several species the light has a regulatory effect on the development and behavior of fungi (Corrochano, 2007; Pulz and Massola Jr., 2009).

The quality and intensity of light are also important aspects to promote in vitro sporulation of $D$. bryoniae.
During preliminary tests (unpublished data), it was possible to stimulate the formation of reproductive structures when using a 12-hour photoperiod with tubes placed $25 \mathrm{~cm}$ away from the lights, however, sporogenesis or spore maturation did not occur. Chiu and Walker (1949) also observed the formation of reproductive structures without the presence of spores. These authors report that the absence of sporulation on the material used occurred due to specific nutritional requirements by the different isolates of $D$. bryoniae. Considering that in the natural environment the fungus receives appropriate quality and amount of light to sporulate, these factors (number of light hours, intensity, and spectrum) are key elements that need to be considered under laboratory conditions to promote satisfactory sporulation of this fungi. 
During the first phase of the experiment, the appearance of reproductive structures occurred both on the surface and submerged in the culture medium, which is why maceration was defined as the best method for obtaining the spores produced. Similar behavior was observed by Leach (1962) when working with the sporulation of the fungus Ascochyta pisi. During preliminary evaluations, it was observed that the sporulation induction occurred in young mycelia only, soon after their exposure to UV-B light. On the other hand, there was no induction when mature mycelia were placed under UV-B light (personal communication). Leach (1962) also reported that young mycelium is more sensitive to UV light radiation acting as a receptor compared to mature mycelium.

The fungal structure type formed varied among the four media used (Table 1). The ML medium showed higher production of perithecia than pycnidia, indicating that there is a higher occurrence of sexual reproduction in this medium caused by the greater availability of essential substances for fungus development. The greater appearance of perithecia might be explained by the fact that sexual reproduction has higher physiological requirements and energy costs compared with asexual reproduction (Chamberlain and Ingram, 1997). Conversely, in other media (PDA, PDAB, and V8) there is less availability of nutritional resources with consequently increased occurrence of asexual reproduction. These results partially corroborate Lee (1982), who obtained different sexual structures of $D$. bryoniae when submitted to PDA, V8, and plant extracts. However, this author attributed the observed differences to the origin of their isolates. In practical terms, the PDAB medium is more suitable to be used when screening to identify resistant plants, since the pycnidiospores produced are more easily visualized and quantified on a hemacytometer. On the other hand, the ML medium is mainly indicated to study genetic aspects of this fungus.

In addition to the influence on the development of reproductive structures, the medium composition also proved to be a determining factor for the size of pycnidiospores. In the V8 medium, there was a higher proportion of microconidia compared to all other media. In this case, the carbon source may be responsible for the variation observed in spore size, given that the V8 medium is the only that dextrose was not added. Similar results were observed by Chiu and Walker (1949) and Lee (1982) who associated the conidia size to the type of medium and isolate used.

Regarding the fungus' ability to survive after freezing at $-20^{\circ} \mathrm{C}$, there was no significant difference in average mycelial growth and mycelial growth rate index among the five different periods of freezing as presented in Figure $4(P>0.05)$. This result indicates that the $D$. bryoniae can be stored at low temperatures, maintaining a high ability of survival and growth rate over time. According to Ayala-Zermeño et al. (2017), freezing significantly reduces cellular metabolism, keeping the fungus viable for long periods. Thus, the high viability in the last month of evaluation (Figure 4) suggests that the fungus can remain viable for longer periods than those evaluated in the present study, without significant damage. It is important to highlight that, because of the experimental design it was not possible to systematically assess survivability after five months and, thus, further studies are required to improve our knowledge on this behalf.

Another important aspect that should be highlighted is the fact that the freezing was carried out using the PDAB medium, which biological material contains a high concentration of fungal spores. According to Meryman (1966) and Sakr (2019) spores, sclerotia, and dormant mycelium are the most resistant fungal structures to freezing because their cells have less moisture content. On the other hand, cellular structures with a higher moisture content tend to be more susceptible to damage caused by low temperatures.

To the best of our knowledge, to date, no studies have been developed to identify the main factors related to in vitro sporulation of $D$. bryoniae neither its ability to survive after freezing. Our results showed that it is possible to stimulate the sporulation of this fungus in vitro and that approachable techniques can be used for the storage and conservation of biological material.

In conclusion, this is the first study identifying key elements of light and culture medium affecting the Didymella bryoniae in vitro sporulation and the consequences of freezing during five consecutive months. The spectrum emitted by UV-B light is the main factor promoting in vitro sporulation. Moreover, the culture medium composition influences the type of fungal structure produced, as well as spores' size and quantity. Freezing at $-20^{\circ} \mathrm{C}$ is an efficient technique that can be used to store $D$. bryoniae for at least five months without loss of viability.

\section{Acknowledgements}

This study was financed in part by the Coordenação de Aperfeiçoamento de Pessoal de Nível Superior - Brasil (CAPES) - Finance Code 001, which had no role in study design, data collection and analysis, decision to publish, or preparation of the manuscript. The study was part of the doctoral thesis of the first author, prepared for the Graduate Program in Genetics and Plant Breeding at Universidade Estadual Paulista (UNESP), Faculdade de Ciências Agrárias e Veterinárias, Jaboticabal, SP, Brasil.

\section{References}

AL-BEDAK, O.A., SAYED, R.M. and HASSAN, S.H.A., 2019. A new low-cost method for long-term preservation of filamentous fungi. Biocatalysis and Agricultural Biotechnology, vol. 22, no. 11, pp. 101417. http://dx.doi.org/10.1016/j.bcab.2019.101417.

APARECIDO, C.C., ROSA, E.C., COSTA, I.A.M. and JORGE, C.M., 2018. Avaliação de diferentes métodos para preservação de fungos fitopatogênicos. O Biológico, vol. 80, no. 1, pp. 1-7.

AYALA-ZERMEÑO, M.A., GALLOU, A., BERLANGA-PADILLA, A.M., ANDRADE-MICHEL, G.Y., RODRÍGUEZ-RODRÍGUEZ, J.C., ARREDONDO-BERNAL, H.C. and MONTESINOS-MATÍAS, R., 2017. Viability, purity, and genetic stability of entomopathogenic fungi species using different preservation methods. Fungal Biology, vol. 121, no. 11, pp. 920-928. http://dx.doi.org/10.1016/j. funbio.2017.07.007. PMid:29029699. 
BHAT, Z., DAR, G., BHAT, M. and ANHANGER, M., 2009. Effect of Media, Temperature and $\mathrm{pH}$ on growth and fructification of Didymella bryoniae (Auresw.) Rehm. causing blight in ridge gourd. Applied Biological Research, vol. 11, no. 5, pp. 70-72.

BRAGA, G.U.L., RANGEL, D.E.N., FERNANDES, É.K.K., FLINT, S.D. and ROBERTS, D.W., 2015. Molecular and physiological effects of environmental UV radiation on fungal conidia. Current Genetics, vol. 61, no. 3, pp. 405-425. http://dx.doi.org/10.1007/s00294015-0483-0. PMid:25824285.

CHAMBERLAIN, M. and INGRAM, D.S., 1997. The balance and interplay between asexual and sexual reproduction in fungi. Advances in Botanical Research, vol. 24, pp. 71-87. http://dx.doi. org/10.1016/S0065-2296(08)60071-3.

CHIU, W.F. and WALKER, J., 1949. Morphology and variability of the cucurbit black rot fungus. Journal of Agricultural Research, vol. 78, no. 5, pp. 81-102.

CHOI, I.Y., CHOI, J.N., CHOI, D.C., SHARMA, P.K. and LEE, W.H., 2010. Identification and characterization of the causal organism of gummy stem blight in the muskmelon (Cucumis melo L.). Mycobiology, vol. 38, no. 3, pp. 166-170. http://dx.doi. org/10.4489/MYCO.2010.38.3.166. PMid:23956648.

CORROCHANO, L.M., 2007. Fungal photoreceptors: sensory molecules for fungal development and behaviour. Photochemical E' Photobiological Sciences, vol. 6, no. 7, pp. 725-736. http:// dx.doi.org/10.1039/b702155k. PMid:17609765.

GRUBE, M., FÜRNKRANZ, M., ZITZENBACHER, S., HUSS, H. and BERG, G., 2011. Emerging multi-pathogen disease caused by Didymella bryoniae and pathogenic bacteria on Styrian oil pumpkin. European Journal of Plant Pathology, vol. 131, no. 3, pp. 539-548. http://dx.doi.org/10.1007/s10658-011-9829-8.

GUSMINI, G., ELLINGTON, T.L. and WEHNER, T.C., 2003. Mass production of gummy stem blight spores for resistance screening. Report - Cucurbit Genetics Cooperative, vol. 26, pp. 26-30.

HASSAN, M.Z., ROBIN, A.H.K., RAHIM, M.A., NATARAJAN, S., KIM, H.T., PARK, J.I. and NOU, I.S., 2018. Screening of melon genotypes identifies gummy stem blight resistance associated with Gsb1 resistant loci. Journal of Plant Biotechnology, vol. 45, no. 3, pp. 217-227. http://dx.doi.org/10.5010/JPB.2018.45.3.217.

HAWKSWORTH, D.L. and COLWELL, R.R., 1992. Microbial diversity: biodiversity amongst microorganisms and its relevance. Biodiversity and Conservation, vol. 1, no. 4, pp. 221-226. http:// dx.doi.org/10.1007/BF00693760.

KEINATH, A.P., FARNHAM, M.W. and ZITTER, T.A., 1995. Morphological, pathological, and genetic differentiation of Didymella bryoniae and Phoma spp. isolated from cucurbits. Phytopathology, vol. 85, no. 3, pp. 364-369. http://dx.doi. org/10.1094/Phyto-85-364.

KWON, M.K., HONG, J.R., SUN, K.Y., CHO, B. and KIM, K.C., 1997. Standardization of a mass-production technique for pycnidiospores of Didymella bryoniae, gummy stem blight fungus of cucurbits. Korean J. Plant Pathol, vol. 13, no. 2, pp. 105-112.

LEACH, C.M., 1962. The quantitative and qualitative relationship of ultraviolet and visible radiation to the induction of reproduction in Ascochyta pisi. Canadian Journal of Botany, vol. 40, no. 12, pp. 1577-1602. http://dx.doi.org/10.1139/b62-154.

LEÃO, E.U., SANTOS, G.R., SARMENTO, R.A., REIS, M.R. and CHAGAS JUNIOR, A.F., 2012. Crescimento micelial e produção de conídios de Ascochyta cucumis em diferentes meios de cultura e regimes de luz. Bioscience Journal, vol. 28, no. 2, pp. 325-331.
LEE, D.H., 1982. Morphological and cultural characters of Didymella bryoniae on seeds and culture media. Kor J Mycol, vol. 10, pp. 7-13.

LIU, S., SHI, Y., MIAO, H., WANG, M., LI, B., GU, X. and ZHANG, S., 2017. Genetic analysis and qtl mapping of resistance to gummy stem blight in Cucumis sativus seedling stage. Plant Disease, vol. 101, no. 7, pp. 1-8. http://dx.doi.org/10.1094/PDIS-08-161116-RE. PMid:30682960.

MAIA, F.G.M., ARMESTO, C., ZANCAN, W.L.A., MAIA, J.B. and DE ABREU, M.S., 2011. Efeito da temperatura no crescimento micelial, produção e germinação de conídios de Colletotrichum spp. isolados de mangueira com sintomas de antracnose. Bioscience Journal, vol. 27, no. 2, pp. 205-210.

MAO, X., WU, Z., BI, C., WANG, J., ZHAO, F., GAO, J., HOU, Y. and ZHOU, M., 2020. Molecular and biochemical characterization of pydiflumetofen-resistant mutants of Didymella bryoniae. Journal of Agricultural and Food Chemistry, vol. 68, no. 34, pp. 9120-9130. http://dx.doi.org/10.1021/acs.jafc.0c03690. PMid:32806116.

MERYMAN, H.T., 1966. Cryobiology. London and New York: Academic Press.

NGA, N.T.T., GIAU, N.T., LONG, N.T., LÜBECK, M., SHETTY, N.P., DE NEERGAARD, E., THUY, T.T.T., KIM, P.V. and JØRGENSEN, H.J.L., 2010. Rhizobacterially induced protection of watermelon against Didymella bryoniae. Journal of Applied Microbiology, vol. 109, no. 2, pp. 567-582. http://dx.doi.org/10.1111/j.13652672.2010.04685.x. PMid:20163499.

PULZ, P. and MASSOLA JR, N.S., 2009. Effect of culture media and physical factors on growth and sporulation of Alternaria dauci and A. solani. Summa Phytopathologica, vol. 35, no. 2, pp. 121126. http://dx.doi.org/10.1590/S0100-54052009000200007.

R DEVELOPMENT CORE TEAM, 2018. R: a language and environment for statistical computing, Vienna, Austria: R Foundation for Statistical Computing.

SAKR, N., 2019. Long term storage for five important cereal phytopathogenic species. Pakistan Journal of Phytopathology, vol. 31, no. 2, pp. 155-162.

SEPÚlVEDA, L., VÁSQUEZ, L.E., PANIAGUA, C.I., ECHEVERRY, D., HERNÁNDEZ, C.A., RODRÍGUEZ, E., RESTREPO, L.F. and ARANGO, R., 2009. The presence and spectrum of light influences the in vitro conidia production of Mycosphaerella fijiensis causal agent of black sigatoka. Australasian Plant Pathology, vol. 38, no. 5, pp. 514-517. http://dx.doi.org/10.1071/AP09036.

SKARSHAUG, A.J., 1981. Centrum development in Didymella bryoniae. American Journal of Botany, vol. 68, no. 8, pp. 1096-1103. http:// dx.doi.org/10.1002/j.1537-2197.1981.tb06393.x.

SOMAI, B.M., KEINATH, A.P. and DEAN, R.A., 2002. Development of PCR-ELISA for detection and differentiation of Didymella bryoniae from related Phoma species. Plant Disease, vol. 86, no. 7, pp. 710-716. http://dx.doi.org/10.1094/PDIS.2002.86.7.710. PMid:30818565.

TORTORA, G.J., FUNKE, B.R. and CASE, C.L., 2011. Microbiologia. 10. ed. Porto Alegre: Artmed, pp. 964.

TSAY, J.G., TZEN, S.L. and TUNG, B.K., 1990. Enhancement of sporulation of Didymella bryoniae by near-ultraviolet irradiation. Plant Protection Bulletin, vol. 32, pp. 229-232.

TSUTSUMI, C.Y. and SILVA, N., 2004. Screening of melon populations for resistance to Didymella bryoniae in greenhouse and plastic tunnel conditions. Brazilian Archives of Biology and Technology, vol. 47, no. 2, pp. 171-177. http://dx.doi.org/10.1590/S151689132004000200002 . 
TUKEY, J. W., 1953. The problem of multiple comparisons. New York: Chapman and Hall. Unpublished memorandum in private circulation.

WIANT, J.S., 1945. Mycosphaerella black rot of cucurbits. Journal of Agricultural Research, vol. 71, no. 5, pp. 193-214.

WOLUKAU, J.N., ZHOU, X.H., LI, Y., ZHANG, Y-B.. and CHEN, J.-F., 2007. Resistance to gummy stem blight in melon (Cucumis melo L.) germplasm and inheritance of resistance from plant introductions 157076, 420145, and 323498. HortScience, vol. 42 , no. 2, pp. 215-221. http://dx.doi.org/10.21273/HORTSCI.42.2.215.

ZHANG, N., XU, B.H., BI, Y.F., LOU, Q.F., CHEN, J.F., QIAN, C.T., ZHANG, Y.B. and YI, H.P., 2017. Development of a muskmelon cultivar with improved resistance to gummy stem blight and desired agronomic traits using gene pyramiding. Journal of Genetics and Plant Breeding, vol. 53, no. 1, pp. 23-29. http://dx.doi. org/10.17221/84/2016-CJGPB. 